\title{
The influence of land use on edge effect in an Atlantic forest fragment in north-east Brazil
}

\author{
Influencia del uso del suelo sobre el efecto de borde en un fragmento de bosque atlántico \\ en el noreste de Brasil
}

\author{
Flávia de B Prado Moura ${ }^{\text {a*, }}$, Mateus Gonzales a, Micheline M Lima ${ }^{\text {b }}$, Marcos V Carneiro Vital ${ }^{\text {c }}$ \\ *Corresponding author: ${ }^{a}$ Universidade Federal de Alagoas (UFAL), Museu de História Natural, Rua Aristeu de Andrade, \\ 452, Farol, CEP 57051-090, Maceió, Alagoas, Brasil, phone: 82-3214 1516, biodiversidade.ufal@gmail.com

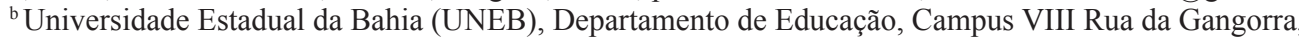 \\ 503 CHESF, CEP 48.608-240, Paulo Afonso, Bahia, Brazil. \\ ${ }^{\mathrm{c}}$ Universidade Federal de Alagoas (UFAL), Instituto de Ciências Biológicas e da Saúde (ICBS), \\ Praça Afrânio Jorge, s/n, Prado, CEP 57010-020, Maceió, Alagoas, Brazil.
}

\begin{abstract}
SUMMARY
Although the edge effect is a phenomenon much studied in tropical forests, the effects of edge creation in open ombrophilous forests of the Atlantic Forest of northeastern Brazil are little discussed. Plant communities with large canopy openness, including periods with partial loss of leaves may respond differently to the impacts of edge formation because species may be more light-tolerant. The matrix can have a direct influence on the edge effect. Most studies available examine the consequences of the interface between forest and agricultural areas or pasturelands. However, the effects of the creation of a water body have been little studied, despite being frequent in the last century. In this study, we analyze the edge effect in two faces of a fragment, the first edge in contact with sugarcane crop, and the second with a lake formed by a dam. To neutralize the effect of selective logging and avoid counting species established before the edge formation, we analyzed the composition and density of the juvenile layer $(\leq 1 \mathrm{~m})$. The results pointed out that the construction of a dam (water body) has caused an edge effect in the forest fragment, which seems to be not relevant in the area adjacent to sugarcane cultivation.
\end{abstract}

Key words: rain forest, fragmentation, edge effect, Atlantic forest, Brazil.

\section{RESUMEN}

Si bien el efecto de borde es un fenómeno ampliamente estudiado en bosques tropicales, los efectos de la creación de bordes en bosques abiertos ombrófilos del bosque atlántico del noreste de Brasil han sido poco discutido. Comunidades vegetales con una gran apertura de copa, incluyendo periodos con pérdida parcial de hojas pueden responder de manera diferenciada a los impactos de la formación de bordes ya que las especies pueden ser más tolerantes a la luz. La matriz puede tener una influencia directa sobre el efecto de borde. La mayoría de los estudios disponibles examinan las consecuencias de la interface entre el bosque y las áreas agrícolas o praderas. Sin embargo, los efectos de la creación de un cuerpo de agua han sido poco estudiados a pesar de ser frecuentes en el último siglo. En este estudio se analiza el efecto de borde en dos lados de un fragmento, el primer borde en contacto con un cultivo de caña y el segundo con un lago formado por una represa. Para neutralizar el efecto de madereo selectivo y evitar el conteo de especies establecidas antes de la formación del borde, se analiza la composición y densidad de la capa juvenil $(\leq 1 \mathrm{~m})$. Los resultados indican que la construcción de una represa (cuerpo de agua) ha causado un efecto de borde en el fragmento de bosque, que parece no ser relevante en el área adyacente al cultivo de caña.

Palabras clave: bosque lluvioso, fragmentación, efecto de borde, bosque atlántico, Brasil.

\section{INTRODUCTION}

Distribution patterns of species near forest edges have been one of the most studied phenomena in ecology in recent decades (Laurance 1990, Mathias et al. 2007, Numata et al. 2009, Ribeiro et al. 2009). In Brazil, most studies have been accomplished in closed canopy Amazon forests where the formation of an edge drastically changes the community. For communities with a more open canopy, such as the Atlantic Forest of northeastern Brazil that has periods with partial loss of leaves, little is known. Perhaps these communities respond differently to the impacts of an edge formation, since their species are more adapted to the presence of light.

The Atlantic Forest of northeastern Brazil is the biogeographical unit of Atlantic forest with higher probability to lose species at the regional scale due to fragmentation (Silva and Tabarelli 2000). In Alagoas State, the forest cover was fragmented into 4,429 patches totaling a forest area of $1,926 \mathrm{~km}^{2}$ (Menezes 2010) most fragments are 
small and with high edge/interior ratio. The present study analyzed the edge effect in a fragment of an open rain forest in two different interfaces - the first oriented toward a sugarcane crop, and the second, to a lake formed by a dam. This paper aims at identifying differences in density and/ or species richness between these two interfaces and how both variables respond to an edge-interior gradient.

\section{METHODS}

The studied fragment $\left(09^{\circ} 25^{\prime}\right.$ and $09^{\circ} 26^{\prime} \mathrm{S}$ and $35^{\circ}$ $42^{\prime}$ e $35^{\circ} 41^{\prime} \mathrm{W}$ ) had a total area of 283 hectares of open rain forest, in the Alagoas State (Assis 2000). The fragment of vegetal cover, was limited by sugarcane crops and by the lake of a dam used for agricultural irrigation. The 86.6 ha dam was built in 2001, whereas the sugarcane field was established in the 1970s (figure 1).

Thirty transects $(5 \times 50 \mathrm{~m})$ were marked, oriented from the edge towards the interior, 15 transects were established in the interface of the fragment oriented towards sugarcane crops, and 15 to the water body. Each transect was subdivided into 10 contiguous plots $(5 \times 5 \mathrm{~m})$ in an edgeinterior gradient (figure 2). In order to establish a model that could indicate the effects on the future flora, from the recruitment analysis, the survey was based on the sample of juvenile individuals, with height $\geq 1 \mathrm{~m}$ and diameter at breast height $(\mathrm{DBH})<5 \mathrm{~cm}$. The distribution of the most abundant species (those with overall total density greater than 30 individuals) was also examined.

The species classification, considering the successional category, was made based on available literature (Lorenzi 1998, Silva and Tabarelli 2000). Species richness and density at the $5 \times 5 \mathrm{~m}$ plots were both analyzed with generalized linear models (GLM) presuming normal distribution. Each model started with three explanatory variables and all possible interactions between them: distance from the

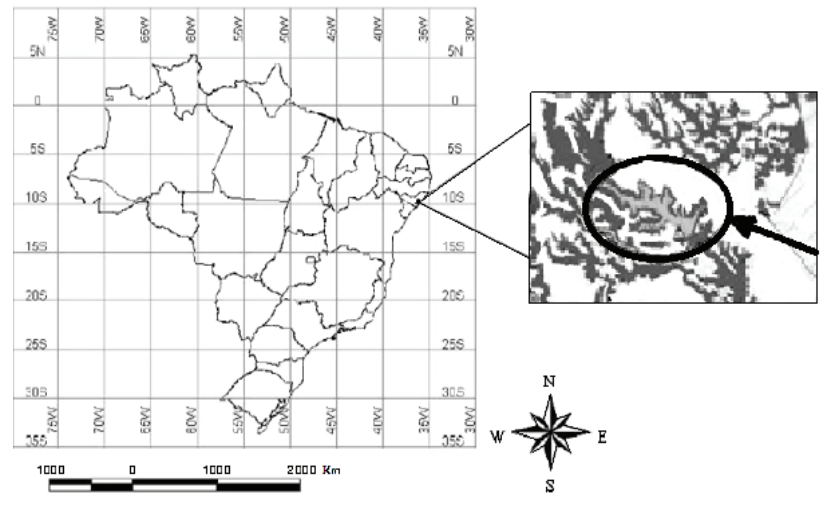

Figure 1. Location of the study area. Study area: fragment of open rain forest, isolated by the sugarcane cultivation, and the lake formed by a dam.

Ubicación del área de estudio. Área de estudio: fragmento de un bosque lluvioso abierto, aislado por un cultivo de caña y por un lago formado por una represa.

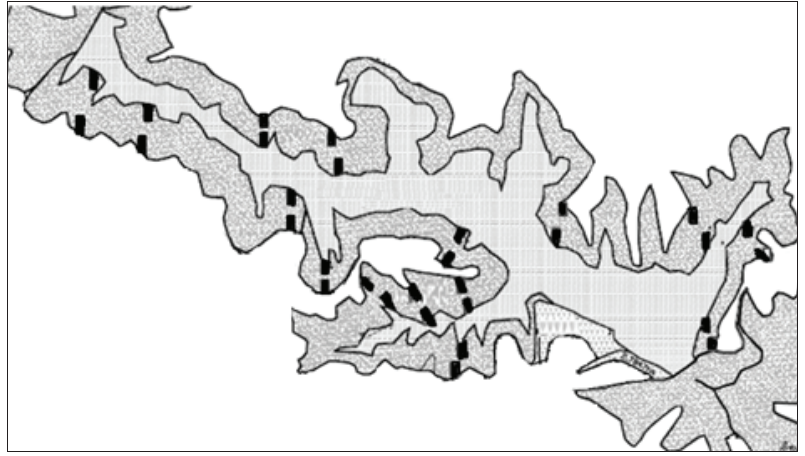

Figure 2. Illustration of the transects distribution along the fragment.

Ilustración de la distribución de transectos a lo largo del frag-

mento.

plot to the edge (measured in meters), sampled transect (the 30 transects are paired, as can be seen in figure 2) and surrounding environment (either sugarcane field or the water body). Next, each model was simplified following a backwise procedure: non-significant interactions were removed, starting from highest level interactions and highest $P$ values. Finally, the simplified models assumptions were verified using Levene tests for variance homogeneity and Shapiro-Wilk tests for normality of models residuals.

\section{RESULTS}

At the juvenile layer, 168 species were recorded. The diversity in the adjacencies to the water body was similar to those found at the edge adjacent to the sugarcane with Simpson index values of 0.020 and 0.018 , respectively. The density of both fragment faces was also similar, 3,851 individuals ha ${ }^{-1}$ and 3,429 individuals ha ${ }^{-1}$, respectively. For both faces, the family Myrtaceae featured higher species richness (28), followed by Fabaceae (20) and Rubiaceae (18). The two faces were also similar regarding floristic composition (Sorensen $=0.76$ ). All species with more than 30 individuals sampled occurred in both studied faces.

Both statistical models violated the residuals normality assumption verified with the Shapiro-Wilk test (richness $\mathrm{W}=0.982, P \leq 0.001$; density $\mathrm{W}=0.973, P \leq 0.001$ ), and the species richness model also violated the assumption of variance homogeneity verified by the Levene's test $(\mathrm{F}=1.847, P=0.007)$. These models, therefore, cannot be used as reliable sources to explain the variation in the collected data. In order to carry on with data analysis, we then decided to simplify our approach by using simple linear regression, which is known to be robust to assumptions violations. To avoid potential noise from the interactions, we independently analyzed data from each surrounding environments, then performing four independent regressions (two for each response variable).

The simple linear regression analyses showed that at the edge surrounded by the lake, both species richness 
$\left(\mathrm{r}^{2}=0.034 ; P=0.024 ; \mathrm{y}=5.64-0.15 \mathrm{x}\right)$ and density $\left(\mathrm{r}^{2}=0.082 ; P \leq 0.001 ; \mathrm{y}=10.91-0.50 \mathrm{x}\right)$ were reduced while the distance from the edge increases, albeit the correlation coefficients were very low. The same relationships were not statically significant at the edge surrounded by sugarcane field, neither for species richness $(P=0.30)$ nor for density $(P=0.20)$. Since the variation on both variables in both surrounding environments was very high, the data was not displayed in scatterplots, as can be seen in figures $3 \mathrm{~A}$ and $3 \mathrm{~B}$.

To Henrietia sucosa (Aubl.) DC. and Myrcia lasiopus DC., the pattern of greater density in relation to the proximity to the edge was significant only in the face oriented toward the dam. Cecropia pachystachya Mart. ex Miq. and Solanum paniculatum L. presented significant variation in both faces, with higher density in the plots of the edge.
Five climax species were recorded: Sorocea bonplandii (Baill.) Burger, Xylopia ochrantha (Mart.) Kuntze, Discophora guianenses Miers., Manilkara rufula (Miq.) H.J. Lam and Pouteria bangii (Rusby) T.D. Penn. Of these species (figure 4), only $X$. ochrantha and $D$. guianenses had significant distribution pattern as a function of edgeinterior gradient. Due to the low number of individuals found $(<30)$, common to climax species, an analysis of distribution patterns of these species was not undertaken, comparing the two faces of the fragment. Nevertheless, all five species occurred in the two faces of the forest.

\section{DISCUSSION}

The analyses along the edge-interior gradient shows that richness and density decrease as distance from the

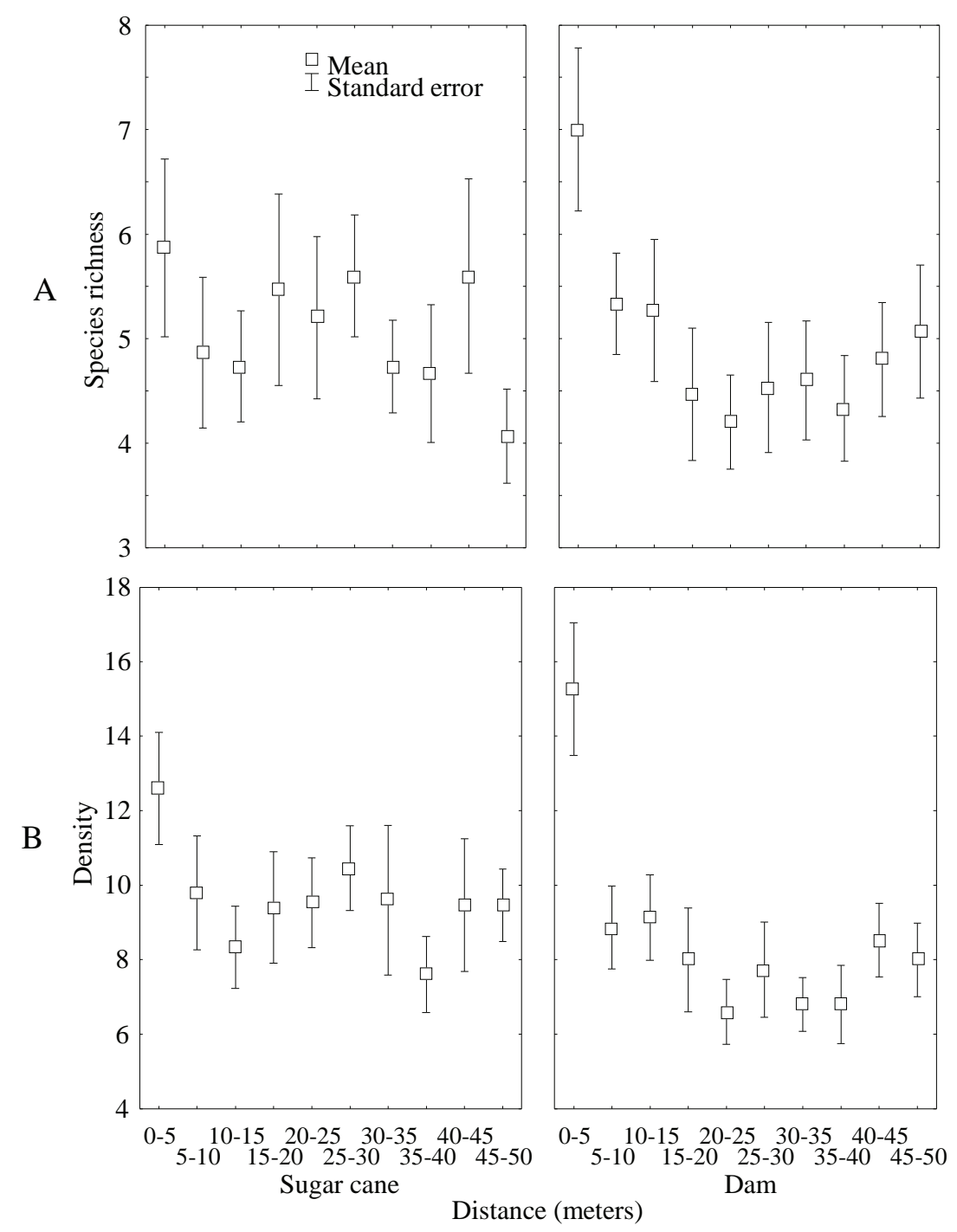

Figure 3. Mean values (and standard error) of the number of species, in plots distributed over edge-interior gradient, plots situated in the face oriented toward the sugarcane crops, and plots situated in the face oriented toward the lake of the dam.

Valores medios (y error estándar) del número de especies en parcelas distribuidas a lo largo del gradiente borde-interior, parcelas situadas en la cara orientada hacia el cultivo de caña, y parcelas situadas en la cara orientada hacia el lago de la represa. 


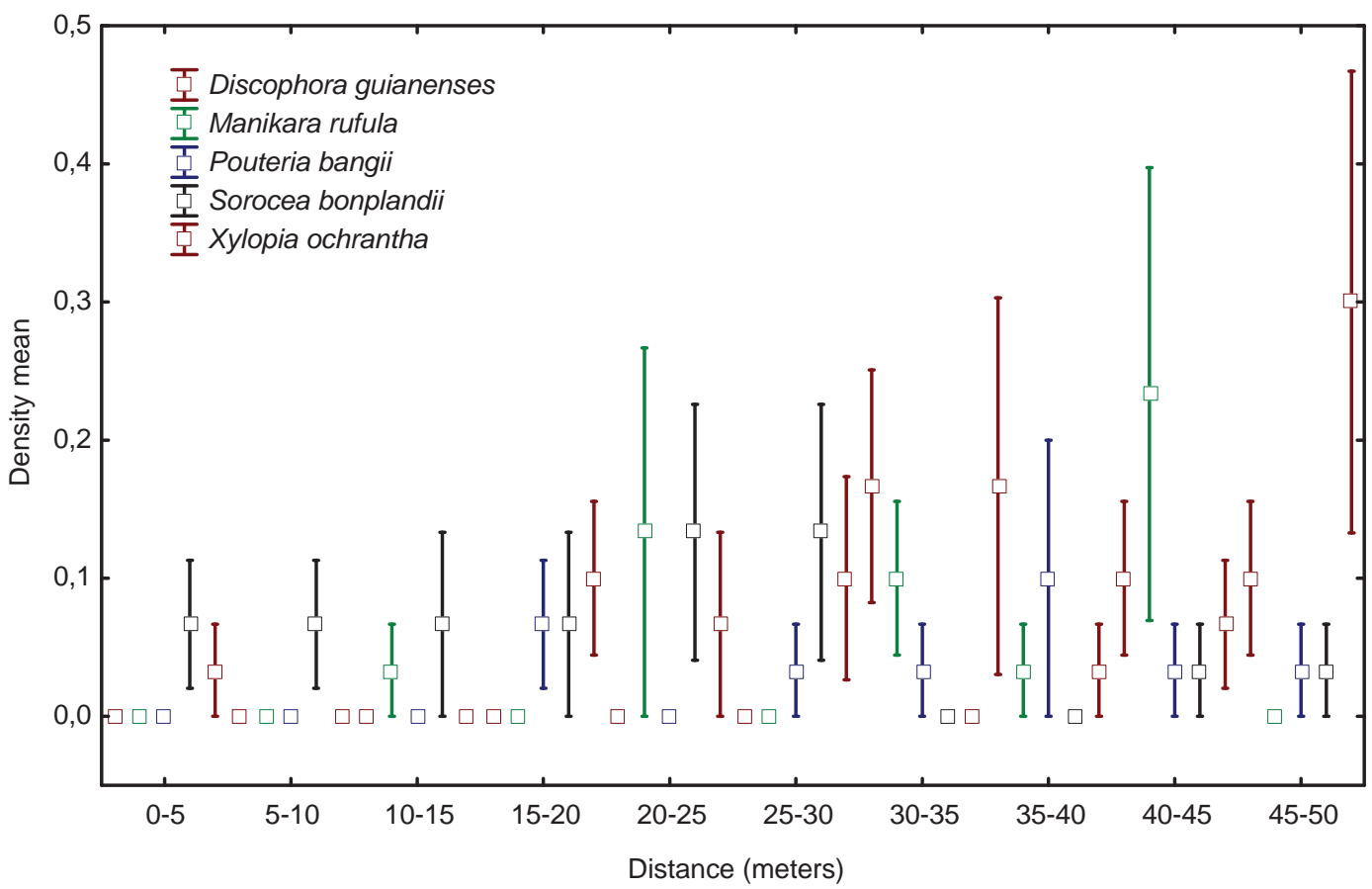

Figure 4. Mean values (and standard error) of the density of individuals, in plots distributed over edge-interior gradient, plots situated in the face oriented toward the sugarcane crops, and plots situated in the face oriented toward the lake of the dam.

Valores medios (y error estándar) de la densidad de individuos, en parcelas distribuidas sobre el gradiente borde-interior, parcelas situadas en la cara orientada hacia el cultivo de caña, y parcelas situadas en la cara orientada hacia el lago de la represa.

edge increases only for the face oriented toward the water body. A similar pattern of distribution with higher richness and heterogeneity in the plots closer to the edge is also observed by Fox et al. (1997), in the rainforests of Australia. Oosterhoorn and Kappelle (2000) also present similar results in a forest in Costa Rica. Besides this, Gehlhausen et al. (2000) show, in different locations, that species richness is correlated with environmental variables, like canopy openness and soil moisture, two variables that usually vary as a function of the edge-interior gradient (Cadenasso et al. 1997). Meanwhile, for tropical forests, little is known about the edge effects in fragments oriented toward the water body of human origin.

At the face oriented toward the dam, the species H. sucosa and M. lasiopus, considered pioneers in the successional stage, present a pattern of higher density in relation to the proximity to the edge. The species $S$. paniculatum present higher density at the face oriented toward the sugarcane than toward the dam (32 and 04 individuals, respectively), which can be ascribed to the fact that they are invasive species that are more likely to reach the forest through the face oriented towards the sugarcane.

In the analysis of the climax species, only $X$. ochrantha and $D$. guianenses show a significant pattern of distribution as a function of the edge-interior gradient, with prominence of $D$. guianenses, found in the plots located $30 \mathrm{~m}$ from the edge. Although considered as climax species, S. bonplandii, M. rufula and P. bangii do not present a significant pattern of distribution over the edge-interior gradient. This pattern, added to the fact that only one of these climax species was not sampled in plots near the forest edge, may result from the fact that the region's rain forest is relatively open, so the above-mentioned species might be used to some degree of light exposure. Probably, species or populations of species that evolve in the presence of larger natural openness of the canopy suffer less the impacts of the edge formation than those species from dense rain forest. The absence of edge effects in open tropical formations has also been reported by Queiroga and Rodrigues (2005) and Santos and Santos (2008), for areas of Caatinga and Cerrado, in Brazil. The opposite has been verified in dense forests, such as the Amazon (Laurance et al. 1998). It is possible that the effect of the formation of an edge is inversely proportional to the natural openness of the canopy.

\section{CONCLUSIONS}

The difference in the distribution of species richness and density of individuals over the edge-interior gradient, that is present only in the face of the fragment oriented toward the lake of the dam, is an important indicative that the creation of the dam has a greater edge effect on the forest fragment than the cultivation of sugarcane as both species richness and density decrease while the distance from the edge increases. However, these results should 
not be generalized, since little is known about the edge effects caused by a water body. Many species appear to be indifferent to the edge effect. Possibly, these species or populations that live in the open ombrophilous forest are more adapted to the presence of light. It is important to point out that two climax species - $X$. ochrantha and $D$. guianenses- show a significant pattern of distribution as a function of the edge-interior gradient. These species may demand greater conservation efforts.

\section{ACKNOWLEDGEMENTS}

The authors are grateful to the Curator of the MAC Herbarium, Dr. Rosângela Pereira de Lyra Lemos, and to her team, especially to Maria Noêmia Rodrigues and Flávia Cavalcante, for the support on plants identification. A Ana C M Malhado, Everando VSB Sampaio e Elcida L Araújo for their comments on early drafts of this paper. We are also grateful to three anonymous referees for valuable comments on the submitted manuscript.

\section{REFERENCES}

Assis JS. 2000. Biogeografia e conservação da biodiversidade. Projeções para Alagoas. Maceió, Brasil. Ed. Catavento. $200 \mathrm{p}$.

Cadenasso ML, MM Traynor, STA Pickett. 1997. Functional location of forest edges: gradients of multiple physical factors. Canadian Journal of Forest Research 27: 774-782.

Fox BJ, JE Taylor, MD Fox, C Williams. 1997. Vegetation changes across edges of rainforest remnants. Biological Conservation 82: 1-13.

Gehlhausen SM, MW Schwartz, CK Augspurger. 2000. Vegetation and microclimatic edge effects in two mixed-mesophytic forest fragments. Plant Ecology 147: 21-35.
Laurance FW. 1990. Edge effects in tropical forest fragments: application of a model for design of nature reserves. Biological Conservation 57: 205-219.

Laurance WF, LV Ferreira, JM Rankin-de Merona, SG Laurance, RW Hutchings, TE Lovejoy. 1998. Effects of forest fragmentation on recruiment patterns in Amazonian tree communities. Conservation Biology 12(2): 460-464.

Lorenzi H. 1998. Árvores brasileiras: manual de identificação e cultivo de plantas arbóreas do Brasil. Vols 1 e 2. São Paulo. Editora Plantarum. 352 p.

Mathias H, JM Roberts, PTW Rosier, ET Miche`le, DJ Gowing. 2007. Edge effects and forest water use: A field study in a mixed deciduous woodland. Forest Ecology and Management 250: 176-186.

Menezes AF. 2010. Cobertura vegetal do Estado de Alagoas e Mangues de Alagoas. Maceió, Brasil. Editora UFAL. 202 p.

Numata I, MA Cochrane, DA Roberts, J Soares. 2009. Determining dynamics of spatial and temporal structures of forest edges in South Western Amazonia. Forest Ecology and Management 258: 2547-2555.

Oosterhoorn M, M Kappelle. 2000. Vegetation structure and composition along an interior-edge-exterior gradient in a Costa Rican montane loud forest. Forest Ecology and Management 126: 291-307.

Queiroga LJ, E Rodrigues. 2005. Efeito de borda em fragmentos de cerrado em áreas de agricultura no Maranhão. Available in: www.uel.br/cca/agro/ecologia_da_paisagem/tese/ joel_borda.pdf

Ribeiro MT, FN Ramos, FA Santos. 2009. Tree structure and richness in an Atlantic forest fragment: distance from anthropogenic and natural edges. Revista Árvore 33: 112-113.

Santos AMM, BA Santos. 2008. Are the vegetation structure and composition of the shrubby Caatinga free from edge influence? Acta Botânica. Brasilica 22: 1077-1084.

Silva JMC, M Tabarelli. 2000. Tree species impoverishment and the future flora of the Atlantic forest of northeast Brazil. Nature 404: 72-74. 